\title{
Effect of Isothermal Aging and Copper Substrate Roughness on the SAC305 Solder Joint Intermetallic Layer Growth of High Temperature Storage (HTS)
}

(Kesan Penuaan Isoterma dan Kekasaran Permukaan Substrat Kuprum ke atas Pertumbuhan Lapisan antara Logam Sambungan Pateri SAC305 pada Penyimpanan Suhu Tinggi (HTS))

\author{
Rabiah Al AdawiYah Ab Rahim, MuHAmmad Nubli Zulkifli, AZMAn Jalar*, AtiQAh Mohd \\ AFDZALUDDIN \& KIM SIOW SHYONG
}

\begin{abstract}
This study aims to evaluate the effect of copper (Cu) substrate surface roughness on the intermetallic compound (IMC) growth and interfacial reaction of SAC305 lead-free solder joint after undergone an aging process. Aging process was conducted using high temperature storage (HTS) at temperature of $150{ }^{\circ} \mathrm{C}$ and aging times of 200, 400, 600, 800, and 1000 h. IMC morphology and growth were examined using infinite focus microscope (IFM). Then, the SAC305 solder joint IMC growth kinetic was measured based on power law relationship and diffusion coefficient formula. It was noted that the morphology of IMC for the rougher Cu substrate has scallop-shaped and uniform layer as compared to that of smoother Cu substrate for the initial exposure to the HTS. In addition, Cu substrate with $R_{a}$ of $579 \mathrm{~nm}$ is the turning point for the creation of $\mathrm{Cu}_{6} \mathrm{Sn}_{5}$ towards more $\mathrm{Cu} \mathrm{u}_{3} \mathrm{Sn}$ of IMC. In addition, Cu substrate with $\mathrm{R}_{a}$ of $579 \mathrm{~nm}$ also acts as the turning point for the IMC growth of SAC305 solder joint on Cu substrate for the solid-state diffusion to be happened during $150^{\circ} \mathrm{C}$ of aging from grain boundary dominant toward volume diffusion dominant.
\end{abstract}

Keywords: High temperature storage (HTS); IMC layer growth, IMC thickness; SAC305 solder; substrate roughness

ABSTRAK

Kajian ini bertujuan untuk menilai kesan kekasaran permukaan substrat kuprum (Cu) ke atas pertumbuhan lapisan sebatian antara logam (IMC) dan tindak balas antara muka sambungan pateri SAC305 selepas melalui proses penuaan. Proses penuaan dijalankan menggunakan penyimpanan suhu tinggi (HTS) pada suhu $150{ }^{\circ} \mathrm{C}$ dan masa penuaan 200, 400, 600, 800 dan 1000 jam. Morfologi dan pertumbuhan IMC dicerap menggunakan mikroskop fokus tak terjangka (IFM). Kemudian, pertumbuhan kinetik sambungan pateri SAC305 diukur berdasarkan hubungan hukum kuasa dan formula pekali resapan. Morfologi IMC untuk substrat Cu yang lebih kasar menunjukkan ia berbentuk kerangan dan lapisan yang seragam berbanding substrat Cu yang lebih licin untuk permulaan pendedahan kepada HTS. Sebagai tambahan, substrat $C u$ dengan $579 \mathrm{~nm} R_{a}$ merupakan titik permulaan kepada pertumbuhan IMC sambungan pateri $S A C 305$ di atas substrat $C u$ untuk resapan keadaan pepejal berlaku semasa penuaan $150{ }^{\circ} \mathrm{C}$ daripada dominan sempadan terhadap dominan resapan isi padu.

Kata kunci: Kekasaran substrat; ketebalan IMC; penyimpanan suhu tinggi (HTS); pertumbuhan lapisan IMC; pateri SAC305

\section{INTRODUCTION}

Lead-free solder joints are widely used as the interconnection mean in the electronic industry. Substrate used as bond pad for the connection of lead-free solder joint are made of different type of metals and copper $(\mathrm{Cu})$ is one of the widely utilised (Abu Bakar et al. 2016; Jalar et al. 2016; Jiang et al. 2019). The quality and the reliability of the connection of solder joints onto the different morphology of $\mathrm{Cu}$ substrates are evaluated by different type of tests like wettability and microstructure evaluations (Ismail et al. 2018a, 2016a; Wang et al. 2017). Wettability is widely used test to measure the adhesion of the solder joint through the contact angle measurement taken right after the application of soldering of molten solder on the substrate (Bhat et al. 2014; Ismail et al. 2016b). However, the determination of solder joint wettability only explains the adhesion and spreading of molten solder through the measurement of the physical appearance. 
Microstructure examination and intermetallic compounds growth kinetic measurement at the interfaces of solder joints and $\mathrm{Cu}$ substrate provide more detail analysis regarding the quality and reliability of solder joints on different morphology of $\mathrm{Cu}$ substrates (Bhat et al. 2014; Ismail et al. 2018b, 2016a). This is because the evaluation based on microstructure and growth kinetic measurement are taken at micrometre scale and at the cross-sectional view that show the internal structure of solder joints with $\mathrm{Cu}$ substrate. Several studies have been conducted to evaluate the microstructure evolution and intermetallic compound (IMC) growth kinetic at the interfaces of lead-free solder with $\mathrm{Cu}$ substrates. Lee and Ahmad Azmin (2013) reported that $\mathrm{SnAgCu}$ (SAC) solder is the most popular type of lead-free solder that has been used as eco-friendly product. They noted that there was two IMC layers commonly found at the interface of SAC solder and $\mathrm{Cu}$ substrate which are $\mathrm{Cu}_{6} \mathrm{Sn}_{5}$ and $\mathrm{Cu}_{3} \mathrm{Sn}$. Both IMCs were growing with the increasing soldering reflow temperature and time. Mo et al. (2015) found that the type of substrate have a significant effect on the IMC microstructure changes. It was noted that the $\mathrm{Cu}$ and $\mathrm{Cu}_{6} \mathrm{Sn}_{5}$ reaction were much faster on the copper-plated substrate compared to that of copper-rolled substrate. They also observed that the increase of dwell time of reflow time has increased the thickness of IMCs. Hu et al. (2016) conducted the isothermal aging at range 150 to 180 ${ }^{\circ} \mathrm{C}$ for $486 \mathrm{~h}$ on the $\mathrm{Sn} 3.0 \mathrm{Ag} 0.5 \mathrm{Cu}$ solder joint with the $\mathrm{Cu}$ substrate. They noted the increment of IMC thickness during aging were following parabolic relationship with time. In addition, they reported that the formation of IMC is mostly controlled by diffusion mechanism. Li et al. (2015) reported that the thickness of $\mathrm{Cu}_{3} \mathrm{Sn}$ in in the SAC305 solder joint and $\mathrm{Cu}$ substrate system is much thinner compared to that of pure $\mathrm{Sn}$ and $\mathrm{Cu}$ system. This is due the inhibiting effect of $\mathrm{Ag}$ and $\mathrm{Cu}$ on the diffusion phenomenon of $\mathrm{Sn}$ atoms into the $\mathrm{Cu}$ substrate.

However, there are quite limited sources that discussing the effect of the $\mathrm{Cu}$ surface roughness towards the growth kinetic of solder joints IMC after the soldering and aging processes. Bhat et al. (2014) carried out a study on the effect of reflow temperatures and substrate surface roughness on the interfacial reaction of SAC387 solder joint on the $\mathrm{Cu}$ substrate. They noted that the morphology or shape of IMCs transformed from long to short needles with the increment of $\mathrm{Cu}$ substrate surface roughness. They also stated that the shear strength of SAC37 solder joint on rougher $\mathrm{Cu}$ substrate has higher value compared to that of smoother $\mathrm{Cu}$ substrate. However, smoother $\mathrm{Cu}$ substrate is preferred due to joint failure mode predominantly occurred in solder matrix as compared that of rougher $\mathrm{Cu}$ substrate where the joint failure mode happened at the interfaces of SAC 387 joint and $\mathrm{Cu}$ substrate.
Although the study about microstructure and mechanical performances of SAC305 solder joint on the $\mathrm{Cu}$ substrate have been conducted quite intensively, but the relationship between $\mathrm{Cu}$ substrate surface roughness towards the reliability and IMC growth kinetic of SAC305 solder joints are still lacking and comprehensive study is critically needed. In the current study, $\mathrm{Cu}$ substrates with different surface roughness were prepared through wet grinding process on different grits of silicon carbide (SiC) abrasive papers. This has created the $\mathrm{Cu}$ substrates with different average surface roughness $\left(\mathrm{R}_{\mathrm{a}}\right)$ of $567,505,477,338,311$, and $172 \mathrm{~nm}$. SAC305 solder joint was hand soldered on the $\mathrm{Cu}$ substrates with different average surface roughness $\left(R_{a}\right)$. Reliability test or aging was carried out the SAC305 solder joints with $\mathrm{Cu}$ substrate using high temperature storage (HTS). The shape or morphology changes and IMC growth were evaluated on the cross-sectional view of interface area between SAC305 solder joint and $\mathrm{Cu}$ substrate. IMC growth kinetic was measured based on the empirical power law relationship and diffusion coefficient formula to evaluate the SAC305 solder joints and $\mathrm{Cu}$ substrate interfacial reaction.

\section{EXPERIMENTAL WORKS}

Different surface roughness of $\mathrm{Cu}$ substrate with size of $25 \times 15 \times 2.5 \mathrm{~mm}$ were prepared by wet grinding the $\mathrm{Cu}$ substrates on the $240,400,600,800,1000$, and 1200 grits of silicon carbide, $\mathrm{SiC}$ abrasive papers. The $\mathrm{Cu}$ substrates were then cleaned with ethanol and deionized (DI) water. Infinite focus microscope (IFM) made of Alicona, was used to evaluate the surface roughness of $\mathrm{Cu}$ substrates that have gone through the wet grinding process. The average roughness $\left(R_{a}\right)$ measurement was obtained using IFM based on the following formula (Anon 2020):

$$
R_{a}=\frac{1}{L} \int_{0}^{L}|Z(x)| d x
$$

where $L$ is the evaluation length and $Z(x)$ is the profile height function. SAC305 lead-free solder wire with diameter of $1.0 \mathrm{~mm}$ was used as solder material for current study. Hand soldering with applied temperature of $300{ }^{\circ} \mathrm{C}$ was conducted to solder the SAC305 lead-free solder wire onto the six different sample of $\mathrm{Cu}$ substrates that have been grounded with six different grit of abrasive papers. This has created six different samples of SAC305 solder joints on $\mathrm{Cu}$ substrates.

High temperature storage (HTS) test was carried out on the six samples of SAC305 solder joints with $\mathrm{Cu}$ substrate using Memmert universal oven based on JESD22-A103C standard with applied temperature of 150 ${ }^{\circ} \mathrm{C}$. Five HTS aging times of 200, 400, 600, 800, and 1000 $\mathrm{h}$ have been chosen to be applied on the six samples of 
SAC305 solder joints with $\mathrm{Cu}$ substrate. This has produced six SAC305 solder joints with $\mathrm{Cu}$ substrate for each five HTS aging time.

After SAC305 solder joints with $\mathrm{Cu}$ substrate was tested with HTS test, the sample was prepared for microstructure examination using metallography procedure by first resin was mounted the samples. When the samples were cured, wet grinding was carried out with $600,800,1200$, and 2000 grits of abrasive papers. Then, the samples were polished with 1 and $0.25 \mu \mathrm{m}$ diamond suspensions on silk cloth. SAC305 solder joints with $\mathrm{Cu}$ substrate was immersed into an etchant solution of 5\% hydrochloric acid (HCL) and 95\% methanol for $10 \mathrm{~s}$, then the sample was rinsed with deionized (DI) water to show the microstructure. Microstructure examination of cross sectioned of SAC305 solder joints with $\mathrm{Cu}$ substrate was performed using IFM. The measurement of intermetallic compounds (IMC) thickness was taken by gathering 100 vertical thickness readings using IFM.

\section{RESULTS AND DISCUSSION}

Figure 1 shows the surface morphology of $\mathrm{Cu}$ substrate grounded by $\mathrm{SiC}$ abrasive papers with grits of 240,400 , $600,800,1000$, and 1200. Figure 2 illustrates the depth versus path length profiles of $\mathrm{Cu}$ substrate grounded by $\mathrm{SiC}$ abrasive grits of 240, 400, ,600, 800, 1000, and 1200 . As shown in Figure 1(a), the surface shows rougher and the depth versus path length profiles curve was less shallow as in Figure 2(a) when the decreasing the number of $\mathrm{SiC}$ abrasive paper grits. When the increasing number of $\mathrm{SiC}$ abrasive paper grits as shown in Figure 1(d), the surface morphology shows smoother and the depth versus path length profiles curve becomes shallower which confirms that the surface roughness is reduced. While in Figure 3 exhibits variation of $\mathrm{Cu}$ substrate, $R$ towards $\mathrm{SiC}$ abrasive paper grits. In Figure 3, it is shown that the trend of $R_{a}$ reduction is not quite in the linear behaviour where the $\mathrm{SiC}$ abrasive paper with grit 240 produces the highest $R_{a}$ of $567 \mathrm{~nm}$ and reduces gradually for grits 400 and 600 with $R_{a}$ of 505 and $477 \mathrm{~nm}$, respectively. For SiC abrasive paper with grit of 800 , the $R_{a}$ value is reduced quite abruptly with value of $338 \mathrm{~nm}$ before gradually decreases to $311 \mathrm{~nm}$ for grit of 1000 . Then, the $R_{a}$ is reduced quite significantly again with value of $172 \mathrm{~nm}$ for 1200 grit. This indicates that the $\mathrm{R}_{\mathrm{a}}$ value is not changed in the linear relationship as compared to that of the increment of grit values of $\mathrm{SiC}$ abrasive papers that have applied where the value is increased with similar difference of grit of 200 except for the grit 240. From Figure 3, it can be identified that the changes of $R_{a}$ of $\mathrm{Cu}$ substrate after grounded by six difference grits of $\mathrm{SiC}$ abrasive paper have three segments. First segment is for the $\mathrm{Cu}$ substrate with $R$ of 567, 505 and $477 \mathrm{~nm}$ where the decrement trend is in gradual manner, followed by second segment that start with abrupt decrement towards $\mathrm{R}_{\mathrm{a}}$ of $338 \mathrm{~nm}$ and then gradual decrement with $R_{a}$ of $311 \mathrm{~nm}$. Third segment is represented with abrupt reduction towards $172 \mathrm{~nm}$ of $\mathrm{R}_{\mathrm{a}}$. Thus, the application of $\mathrm{SiC}$ abrasive papers with grits of 240,400 , $600,800,1000$, and 1200 produce $\mathrm{Cu}$ substrates with $R_{a}$ that can divided into three segments that is represented by the reduction manner in either gradually or abruptly changes.
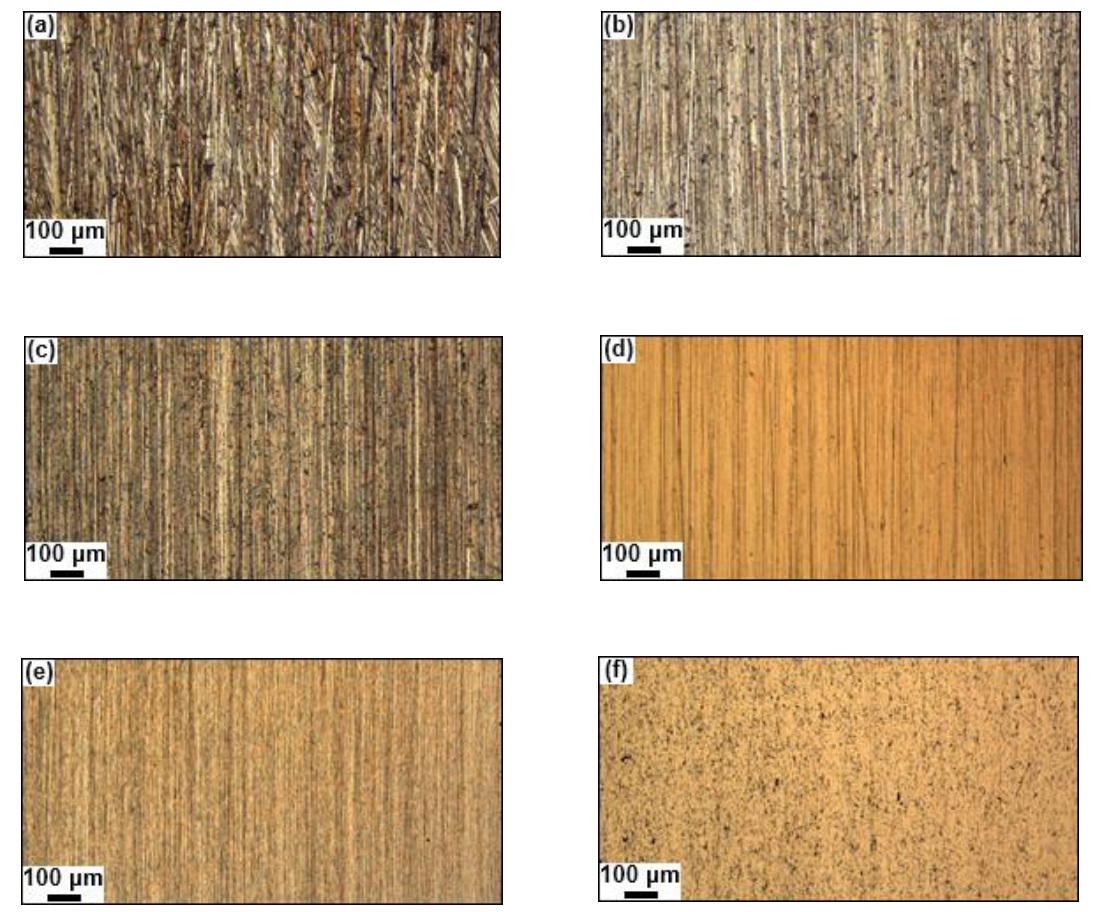

FIGURE 1. Surface morphology of $\mathrm{Cu}$ substrate grounded by $\mathrm{SiC}$ abrasive papers with grits of (a) 240, (b) 400, (c) 600, (d) 800, (e) 1000, and (f) 1200 

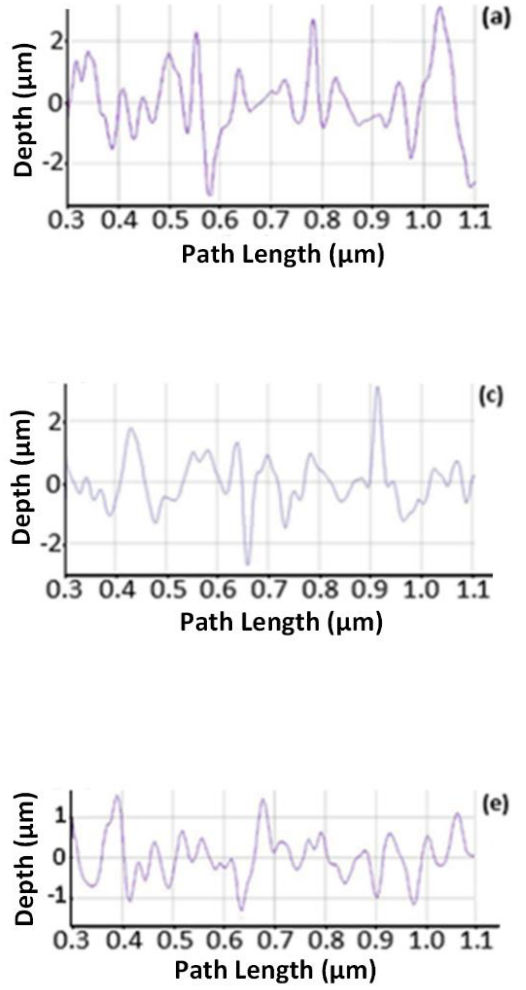
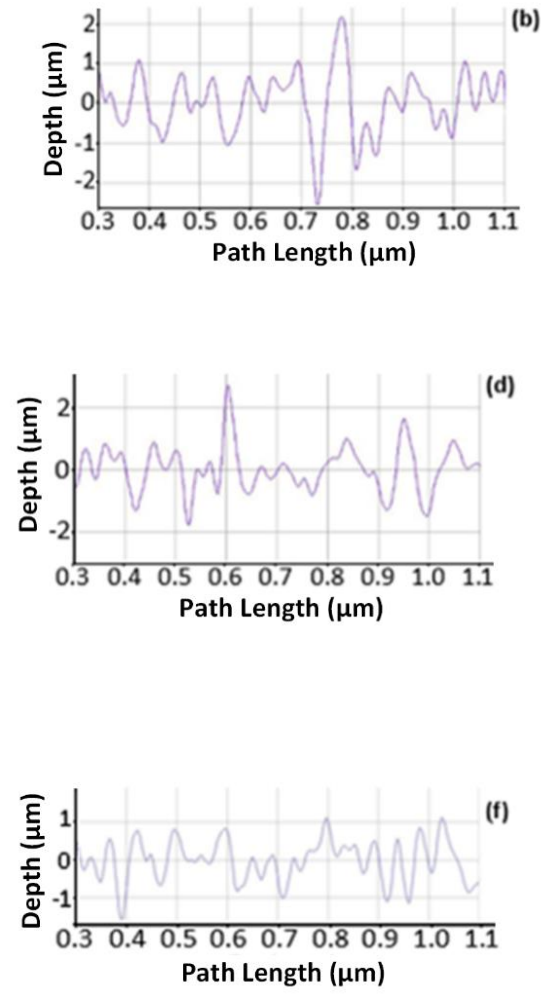

FIGURE 2. Depth versus path length profiles of $\mathrm{Cu}$ substrate grounded by $\mathrm{SiC}$ abrasive papers grits of (a) 240, (b) 400, (c) 600, (d) 800, (e) 1000, and (f) 1200

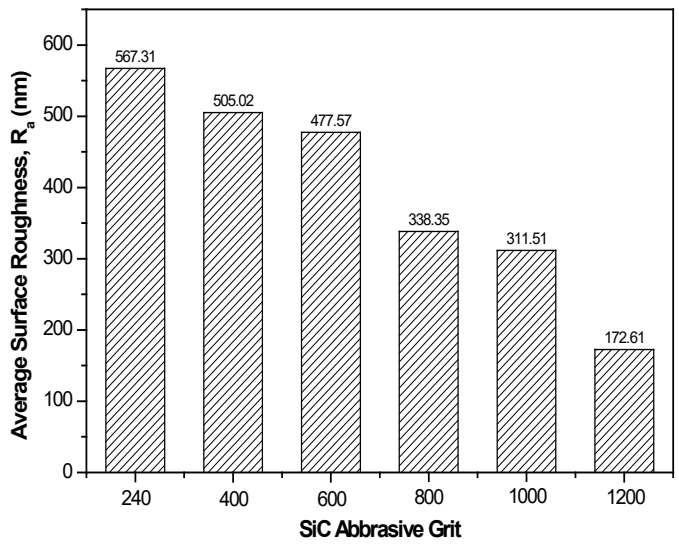

FIGURE 3. Variation of $\mathrm{Cu}$ substrate average surface roughness, $R_{a}$ towards $\mathrm{SiC}$ abrasive grits

Figure 4 shows the micrograph of the cross sectioned at the area of IMC of SAC305 solder joints aged with $150{ }^{\circ} \mathrm{C}$ and aging time of $1000 \mathrm{~h}$. Figure 5 indicates the variation of IMC average thickness towards aging time. In Figure 4, it is noted that there two differences IMC created next to the interface between SAC305 solder joint and $\mathrm{Cu}$ substrate namely $\mathrm{Cu}_{6} \mathrm{Sn}_{5}$ and $\mathrm{Cu}_{3} \mathrm{Sn}$ which are assigned with dotted red and black lines, respectively. 
Several studies have identified the whitish and greyish layers that created at the interface of SAC 305 solder joints with the $\mathrm{Cu}$ substrate were $\mathrm{Cu}_{6} \mathrm{Sn}_{5}$ and $\mathrm{Cu}_{3} \mathrm{Sn}$, respectively (Lee \& Kim 2014; Xiao et al. 2013). Bhat et al. (2014) reported that the IMC created after reflow soldering for the case of SAC305 solder joints on the $\mathrm{Cu}$ substrate have a shape of needle especially for the $\mathrm{Cu}_{6} \mathrm{Sn}_{5}$ and the shape of IMC transformed from long to short needles or scallop-shaped with the increment of $\mathrm{Cu}$ substrate surface roughness. This is attributed to the penetration of molten solder atom occurred in higher degree on the rough surface as compared to that of smooth surface. Satyanarayan and Prabhu (2013) also noted that higher level of asperities possessed by rough surface increase the capillary action for solidification of molten solder on the rough $\mathrm{Cu}$ substrate surface. Therefore, for the as soldered or initial exposure to the HTS, the IMC of SAC305 solder joints on $\mathrm{Cu}$ substrate with rougher surface have scallopshaped and uniform IMC, particularly $\mathrm{Cu}_{6} \mathrm{Sn}_{5}$ as compared to that of the smoother $\mathrm{Cu}$ substrate surface where it has quite non-uniform IMC as shown in Figure 4.
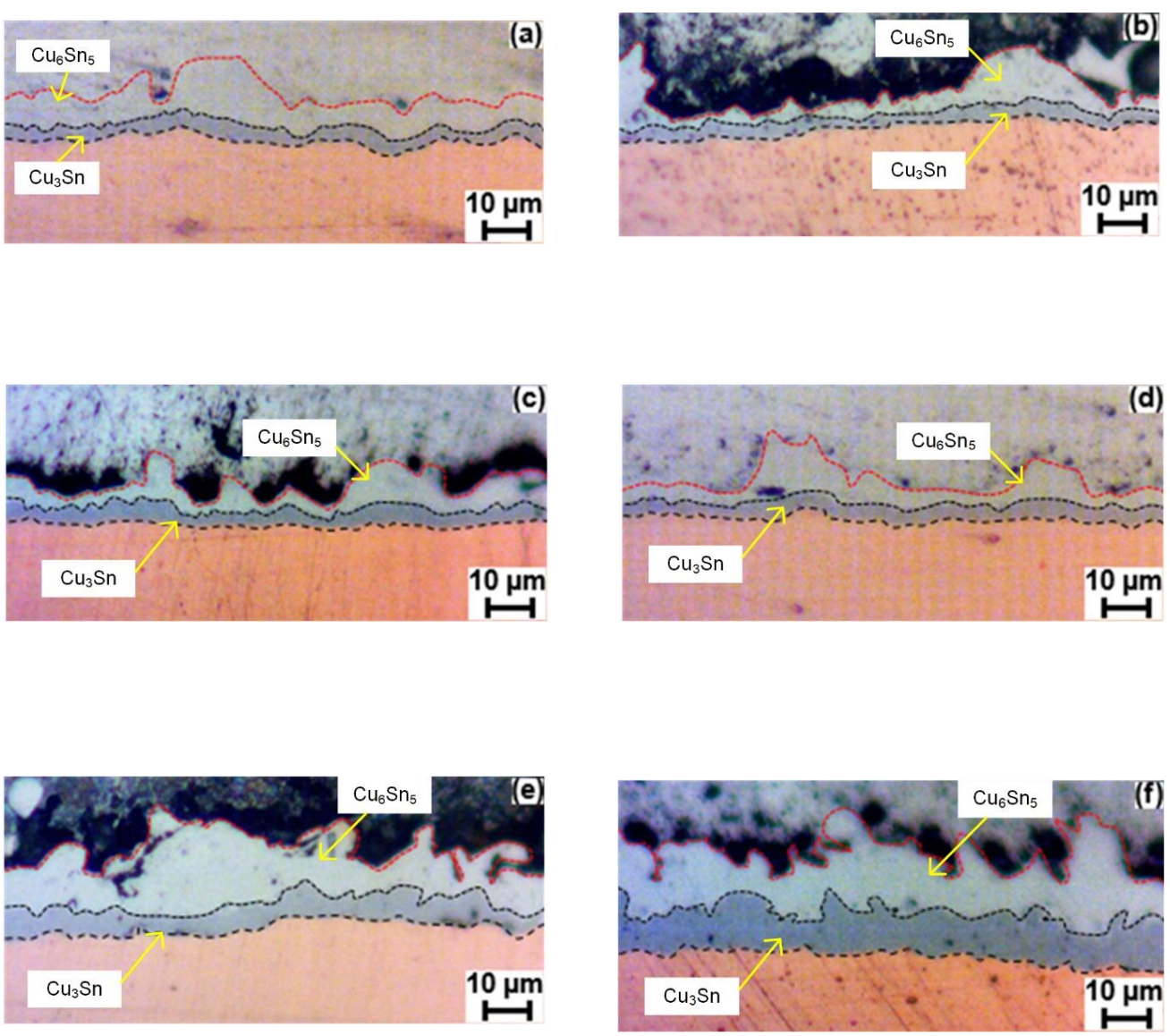

FIGURE 4. Micrographs of the cross sectioned at the area of IMC of SAC305 solder joints aged with $1000 \mathrm{~h}$ and $\mathrm{Cu}$ substrate surface roughness of a) 806 , b) 600 , c) 579 , d) 557 , e) 490 , and f) $340 \mathrm{~nm}$

Figure 5 shows the variation of IMC average thickness towards aging time. As mentioned earlier, the measurement of IMC average thickness was taken from 100 readings of vertical thickness. In Figure 5, it is noted that the IMC average thickness has inversely proportionate relation with the $\mathrm{Cu}$ substrate $R_{a}$ and directly proportionate relation with the aging time. In addition, it is shown that the trend of Figure 5 cannot be divided into three segments of abrupt, gradual and higher slope decrements of $\mathrm{Cu}$ substrate $R_{a}$ as indicated in Figure 3. Furthermore, $\mathrm{Cu}$ substrate with smoothest $R_{a}$ of 340 $\mathrm{nm}$ have the highest and abruptly increment of average thickness especially for the cases of 200,600, and $800 \mathrm{~h}$ of aging time. Therefore, the increment of IMC average 
thickness is not in linear manner with decreasing $\mathrm{Cu}$ substrate $R_{a}$ and increasing aging time which also cannot be divided into three segments as noted in the variation of $\mathrm{Cu}$ substrate $R_{a}$ towards $\mathrm{SiC}$ abrasive grits.

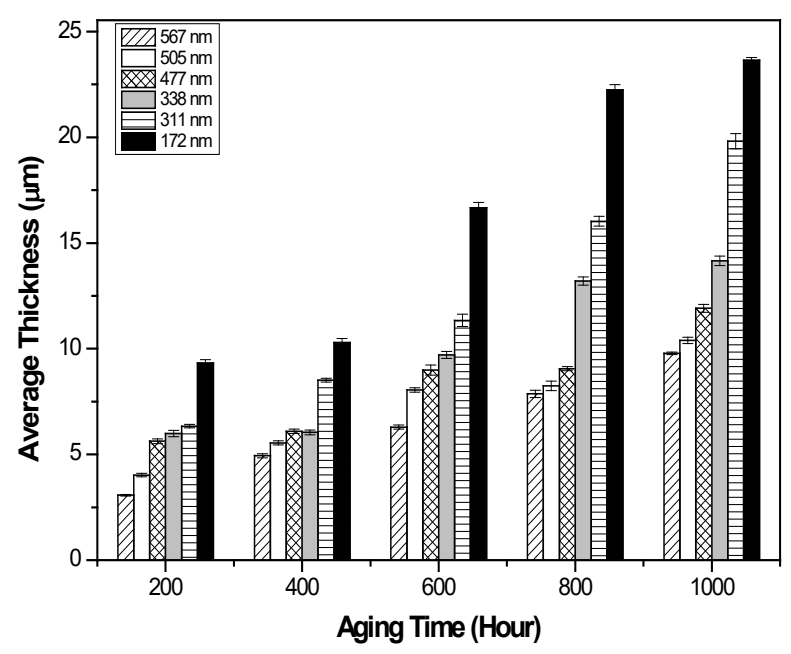

FIGURE 5. Variation of IMC average thickness towards aging time

In order to evaluate the IMC growth rate behaviour and mechanism, time exponent, $\mathrm{n}$ is obtained based on the following empirical power-law relationship (Wang et al. 2018):

$$
x-x_{0}=k t^{n}
$$

where $x$ is the total thickness of the reaction layer at time $t ; x_{o}$ is the initial thickness; $k$ is the growth rate constant; and $n$ is the time exponent. To obtain the time exponent, $n$ linear regression analysis on the logarithmic expression of empirical power-law relationship is carried as follows:

$$
\log \left(x-x_{0}\right)=\log k+n \log t
$$

Then, the graph of $\log \left(x-x_{0}\right)$ vs $\log t$ is plotted as illustrated in Figure 6 where the $R^{2}$ and the slope of the graph are obtained. Figures 7 and 8 exhibit the variation of $R^{2}$ towards $\mathrm{Cu}$ substrate $R_{a}$ and variation of time exponent, $n$ towards $\mathrm{Cu}$ substrate $R_{a}$, respectively. In Figure 7, it is noted that $R^{2}$ has values ranging from 0.79 until 0.99 which mean the growth of SAC305 solder joints IMC obey the parabolic law. From Figure 7, it is shown that time exponent, $n$ values vary across different $\mathrm{Cu}$ substrate $R_{a}$ values with most of it has $n$ value of more than 0.5 that represents the diffusion-controlled IMC growth mechanism except for the $\mathrm{Cu}$ substrate with $R_{a}$ of 477 $\mathrm{nm}$ where the $n$ is equals with 0.46 which represents the chemical reaction-controlled IMC growth mechanism. This means that SAC305 solder joint on $\mathrm{Cu}$ substrate with $R_{a}$ of $477 \mathrm{~nm}$ has the lowest diffusivity rate compared to the rest of $\mathrm{Cu}$ substrates. As mentioned earlier, the measurement of IMC growth for the current study includes both $\mathrm{Cu}_{3} \mathrm{Sn}$ and $\mathrm{Cu}_{6} \mathrm{Sn}_{5}$ IMCs. Therefore, both changes in term of IMC growth are attributed by both IMCs. The $n$ values are decreased for the roughest $\mathrm{Cu}$ substrate with $R_{a}$ of 567 until $477 \mathrm{~nm}$. As mentioned earlier, the rougher $\mathrm{Cu}$ substrates have scallop shapes of IMCs particularly $\mathrm{Cu}_{6} \mathrm{Sn}_{5}$ with the existence of grooves or asperities between each grain of IMC. The existence of groves between the $\mathrm{Cu}_{6} \mathrm{Sn}_{5}$ grains is known to provide the channels for diffusion between $\mathrm{Cu}$ atom from $\mathrm{Cu}$ substrate into $\mathrm{Sn}$ atom in SAC305 solder to be happened. As the $\mathrm{Cu}$ substrate become smoother particularly at $\mathrm{R}_{\mathrm{a}}$ of $477 \mathrm{~nm}$, the creation of $\mathrm{Cu}_{6} \mathrm{Sn}_{5}$ becoming more into planar shape that has lesser groves or channels that hinder the diffusion of $\mathrm{Cu}$ atom from $\mathrm{Cu}$ substrate directly into Sn atom of SAC305 solder. That is why the $n$ for $\mathrm{Cu}$ substrate with $R_{a}$ of $477 \mathrm{~nm}$ has lowest value of 0.456 that represent lower diffusivity process of chemical reaction mechanism (Mo et al. 2015). From Figure 8, it is noted that the $n$ is starts to increase with the smother $\mathrm{Cu}$ substrate with $R_{a}$ of 338 and $311 \mathrm{~nm}$. This increase of diffusivity might be due to the increase of solidstate diffusion between $\mathrm{Cu}$ atom from SAC305 solder with $\mathrm{Sn}$ atom from $\mathrm{Cu}_{6} \mathrm{Sn}_{5}$ which eventually crates the $\mathrm{Cu}_{3} \mathrm{Sn}$ that located in between $\mathrm{Cu}_{6} \mathrm{Sn}_{5}$ and $\mathrm{Cu}$ substrate. According 
to Liu et al. (2018), the increase growth rate of $\mathrm{Cu}_{3} \mathrm{Sn}$ is attributed by the shape of $\mathrm{Cu}_{6} \mathrm{Sn}_{5}$, where the reduction of the channels with planar shape of $\mathrm{Cu}_{6} \mathrm{Sn}_{5}$ has increased the possibility of $\mathrm{Cu}$ atom from $\mathrm{Cu}$ substrate to diffuse into $\mathrm{Cu}_{6} \mathrm{Sn}_{5} \mathrm{IMC}$ and create $\mathrm{Cu}_{3} \mathrm{Sn}$ by the reaction of $\mathrm{Cu}_{6} \mathrm{Sn}_{5}+$ $9 \mathrm{Cu} 5 \mathrm{Cu}_{3} \mathrm{Sn}$. In addition, Tang et al. (2018) reported that the creation of $\mathrm{Cu}_{3} \mathrm{Sn}$ is becoming more apparent for the lead-free solder that have gone through solid-state aging process. Hence, the $\mathrm{Cu}$ substrate with $R_{a}$ of $477 \mathrm{~nm}$ is the turning point for the creation of $\mathrm{Cu}_{6} \mathrm{Sn}_{5}$ towards more $\mathrm{Cu}_{3} \mathrm{Sn}$ due to the closing of the channel of planar shape $\mathrm{Cu}_{6} \mathrm{Sn}_{5}$ that increase the possibility of $\mathrm{Cu}$ atom from $\mathrm{Cu}$ substrate to diffuse into $\mathrm{Cu}_{6} \mathrm{Sn}_{5}$ IMC and create $\mathrm{Cu}_{3} \mathrm{Sn}$.

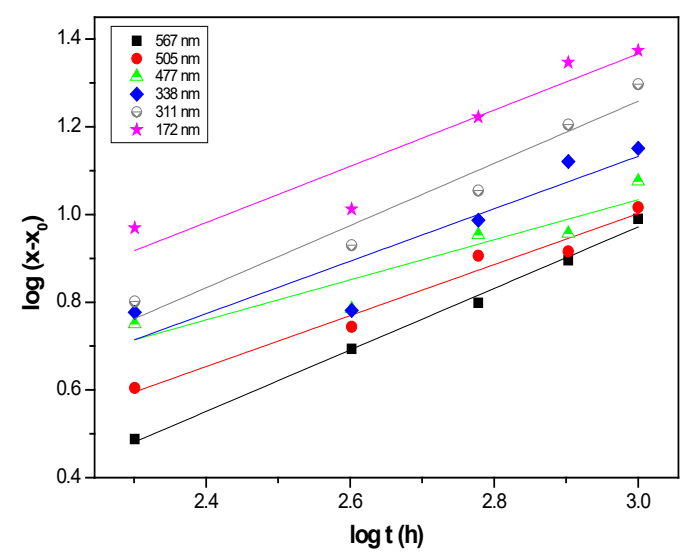

FIGURE 6. Plot of $\log \left(x-x_{o}\right)$ versus $\log t$ to determine the $R^{2}$ and time exponent, $n$ with different $\mathrm{Cu}$ substrates $\mathrm{R}_{\mathrm{a}}$ of 806 , $600,579,557,490$, and $340 \mathrm{~nm}$

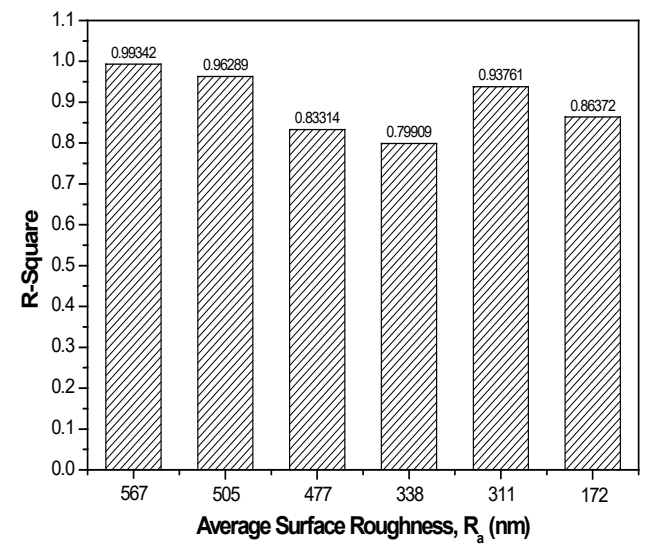

FIGURE 7. Variation of $R^{2}$ towards Cu substrate $R_{a}$

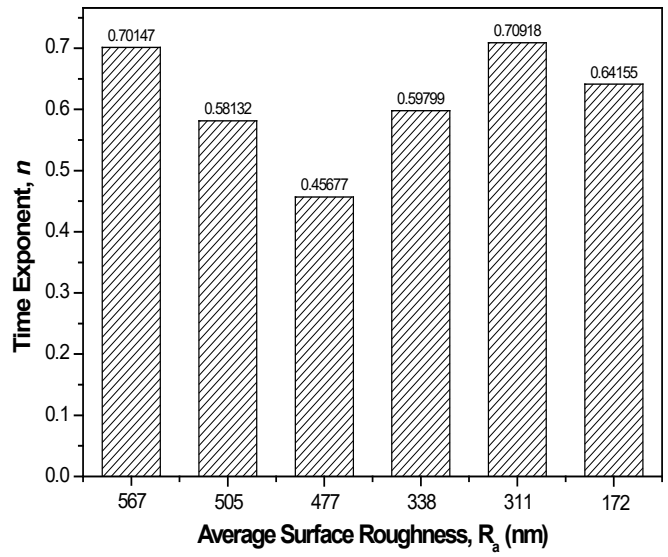

FIGURE 8. Variation of time exponent, towards $\mathrm{Cu}$ substrate $R_{a}$ 
In order to further analyse the solid-state diffusion behaviour that happened during HTS or aging of SAC305 solder joints with different roughness of $\mathrm{Cu}$ substrates, the diffusion coefficient is measured by plotting the IMC thickness versus squared of hour as shown in Figure 9. The plotting of Figure 9 is based on the following layergrowth coefficient or diffusion coefficient formula $(\mathrm{Wu}$ et al. 1993; Yu et al. 2005):

$$
d=d_{0}+\sqrt{K t_{a}}
$$

where $d_{0}$ is the initial thickness of IMC layer $K$ is the layer-growth coefficient that is related to the diffusion coefficient of atomic elements of IMCs and $t$ is time. In Figure 10, it is observed that the diffusion coefficient is decreased gradually for the $\mathrm{Cu}$ substrates with $R_{a}$ of 567 , 505 , and $477 \mathrm{~nm}$ which has the similar reduction trend of $n$ towards $\mathrm{Cu}$ substrate $R_{a}$ as shown in Figure 8. However, the reduction trend of Figure 10 is quite gradual and has least changes as compared to that of Figure 8. According to
Li et al. (2015) the diffusion coefficient of $\mathrm{Cu}$ in Sn during aging with $150{ }^{\circ} \mathrm{C}$ was $2.05 \times 10^{-11} \mathrm{~m}^{2} / \mathrm{s}$ and this value is not that far with current diffusion coefficient with range of $9.726 \times 10^{-10}$ until $2.562 \times 10^{-9} \mathrm{~m}^{2} / \mathrm{s}$. Like that of Figure 8 , the diffusion coefficient of Cu substrate with $R_{a}$ of $477 \mathrm{~nm}$ is the turning point for the diffusion coefficient to increase quite significantly with the decrease of Cu substrate $R_{a}$ of 338,311 , and $172 \mathrm{~nm}$. This might be because the grain boundary diffusion is the dominant factor for the IMC growth in the rougher surface of $\mathrm{Cu}$ substrates with $R_{a}$ of 567,505 , and $477 \mathrm{~nm}$. Whereas, in the smoother surface of $\mathrm{Cu}$ substrates with $R_{a}$ of 338,311 , and $172 \mathrm{~nm}$, the volume diffusion might be the predominant for the IMC growth (Rabiatul Adawiyah \& Saliza Azlina 2018). Thus, Cu substrate with $R_{a}$ of $477 \mathrm{~nm}$ also acts as a turning point for the IMC growth of SAC305 solder joint on $\mathrm{Cu}$ substrate for the solid-state diffusion to be happened during $150{ }^{\circ} \mathrm{C}$ of aging from grain boundary dominant toward volume diffusion dominant.

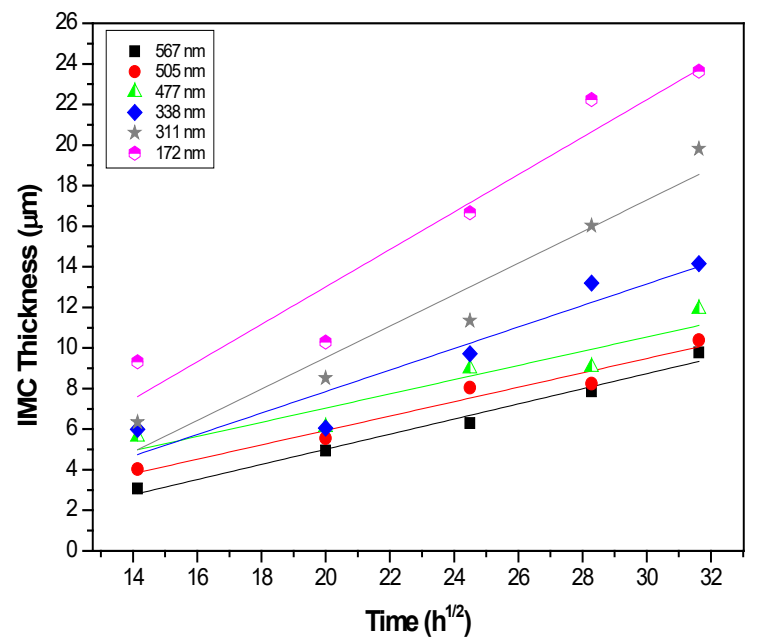

FIGURE 9. Plot of IMC thickness versus time squared to determine the slope or diffusion coefficient with different $\mathrm{Cu}$ substrates $R_{a}$ of $567,505,477,338,311$, and $172 \mathrm{~nm}$

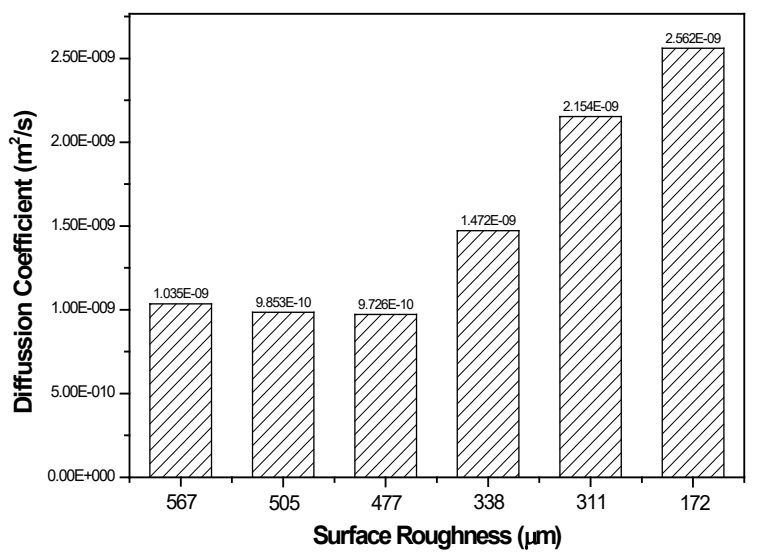

FIGURE 10. Variation of diffusion coefficient versus $\mathrm{Cu}$ substrate $R_{a}$ 
Several studies have identified that the crystallography planes play a role in determining the IMC growth direction. Single crystal and polycrystalline $\mathrm{Cu}$ substrate have shown significant effect on the IMC nucleation and growth (Yang et al. 2017; Zhu et al. 2019). For the current analysis, polycrystalline $\mathrm{Cu}$ have been used as the substrate. This means, the IMC nucleation and growth are in the random locations and directions, respectively. However, the main finding of $\mathrm{Cu}$ substrate with $R_{a}$ of $477 \mathrm{~nm}$ is that it acts as a turning point for the IMC creation from $\mathrm{Cu}_{6} \mathrm{Sn}_{5}$ towards $\mathrm{Cu}_{3} \mathrm{Sn}$ and abrupt changes of diffusion coefficient of SAC305 solder joint signifies that $\mathrm{Cu}$ substrate surface roughness can be used as an IMC growth control mechanism. This is because the combined effects of different IMC nucleation locations and crystallographic directional growth occurred in polycrystalline $\mathrm{Cu}$ substrate can be controlled at certain value of surface roughness as has been shown in the current study. Therefore, the procedure introduces in the current study is the important steps for those who want to determine the suitable $\mathrm{Cu}$ substrate surface roughness to control the IMC growth of SAC305 solder joints.

\section{CONCLUSION}

The evaluation of the interfacial reaction is crucially needed to provide a more comprehensive analysis regarding the effect of $\mathrm{Cu}$ substrate surface roughness on the quality and reliability of SAC305 solder joint. It is noted that, the application of $\mathrm{SiC}$ abrasive papers with grits of 240,400 , $600,800,1000$, and 1200 produce $\mathrm{Cu}$ substrates with $R_{a}$ that can divided into three segments that are represented by the reduction manners in either gradually or abruptly changes. The use of variation of $\mathrm{SiC}$ abrasive paper grit is to indicate the surface roughness of SAC305 with $\mathrm{Cu}$ substrate. The higher number of $\mathrm{SiC}$ abrasive paper grit reduces the surface roughness value obtained by SAC305 with $\mathrm{Cu}$ substrate. For the as soldered or initial exposure to the HTS, the IMC of SAC305 solder joints on $\mathrm{Cu}$ substrate with the rougher surface have scallop-shaped and uniform IMC, particularly $\mathrm{Cu}_{6} \mathrm{Sn}_{5}$ as compared to that of the smoother $\mathrm{Cu}$ substrate surface where it has quite non-uniform IMC. The increment of IMC average thickness is not in linear manner with decreasing $\mathrm{Cu}$ substrate $\mathrm{R}_{\mathrm{a}}$ and increasing aging time which also cannot be divided into three segments as noted in the variation of $\mathrm{Cu}$ substrate $R_{a}$ towards $\mathrm{SiC}$ abrasive grits. Cu substrate with $R_{a}$ of 477 $\mathrm{nm}$ is the turning point for the creation of $\mathrm{Cu}_{6} \mathrm{Sn}_{5}$ towards more $\mathrm{Cu}_{3} \mathrm{Sn}$ due to the closing of the channel of planar shape $\mathrm{Cu}_{6} \mathrm{Sn}_{5}$ that increase the possibility of $\mathrm{Cu}$ atom from $\mathrm{Cu}$ substrate to diffuse into $\mathrm{Cu}_{6} \mathrm{Sn}_{5}$ IMC and create $\mathrm{Cu}_{3} \mathrm{Sn}$. In addition, $\mathrm{Cu}$ substrate with $R_{a}$ of $477 \mathrm{~nm}$ also acts as the turning point for the IMC growth of SAC305 solder joint on $\mathrm{Cu}$ substrate for the solid-state diffusion to be happened during $150^{\circ} \mathrm{C}$ of aging from grain boundary dominant toward volume diffusion dominant. Thus, the procedure introduces in the current study is the important early step for those who want to obtain the suitable $\mathrm{Cu}$ substrate surface roughness to control the IMC growth of SAC305 solder joints.

\section{ACKNOWLEDGEMENTS}

This work is supported by the Ministry of Education, Malaysia under Fundamental Research Grant Scheme (FRGS/1/2019/STG07/UKM/03/1), Universiti Kebangsaan Malaysia (UKM) under Geran Universiti Penyelidikan (GUP-2018-079) and Redring Solder (M) Sdn. Bhd. for research materials and collaboration work.

\section{REFERENCES}

Abu Bakar, M., Azman, J., Roslina, I. \& Abdul, R.D. 2016. Nanoindentation of $\mathrm{Sn} 3 \mathrm{Ag} 0.5 \mathrm{Cu} / \mathrm{ENIG}$ solder joint after high temperature storage. Materials Science Forum 857: 40-43.

Anon. N.D.R. 2020. RMS Surface Roughness Calculation Surface Finish Formulas, Harrison Electropolishing. http:// www.harrisonep.com/electropolishing-ra.html. Accessed on 26 August 2020.

Bhat, K.N., Prabhu, K.N. \& Satyanarayan. 2014. Effect of reflow temperature and substrate roughness on wettability, IMC growth and shear strength of SAC $387 / \mathrm{Cu}$ bonds. Journal of Materials Science: Materials in Electronics 25(2): 864-872.

Hu, X., Xu, T., Keer, L.M., Li, Y. \& Jiang, X. 2016. Microstructure evolution and shear fracture behavior of aged $\mathrm{Sn} 3 \mathrm{Ag} 0.5 \mathrm{Cu} /$ $\mathrm{Cu}$ solder joints. Materials Science and Engineering: A 673: 167-177.

Ismail, N., Jalar, A., Abu Bakar, M. \& Ismail, R. 2018a. Kesan penambahan tiubnano karbon terhadap pertumbuhan lapisan sebatian antara logam sistem pateri $\mathrm{Sn}-\mathrm{Ag}-\mathrm{Cu} / \mathrm{Cu}$ akibat penuaan terma. Sains Malaysiana 47(7): 1585-1590.

Ismail, N., Ismail, R., Jalar, A., Omar, G., Salleh, E.M., Kamil, N. \& Rahman, I.A. 2018b. Comparative study of interfacial interaction between aromatic and aliphatic functional group in solder wettability. Journal of Materials Science: Materials in Electronics 29(15): 12910-12916.

Ismail, N., Ismail, R., Nik Ubaidillah, N.K.A., Jalar, A. \& Zain, N.M. 2016a. Surface roughness and wettability of SAC/ CNT lead free solder. Materials Science Forum 857: 73-75.

Ismail, N., Ismail, R., Abd Aziz, N.I. \& Jalar, A. 2016b. Wettability of CNT-doped solder under isothermal aging. Materials Science Forum 857: 76-78.

Jalar, A., Abu Bakar, M., Ismail, R. \& Abdul, R.D. 2016. Statistical aspect on the measuring of intermetallic compound thickness of lead free solders. Journal of Scientific Research and Development 3(4): 49-54.

Jiang, N., Zhang, L., Liu, Z-Q., Sun, L., Long, W-M., He, P., Xiong, M-Y. \& Zhao, M. 2019. Reliability issues of lead-free solder joints in electronic devices. Science and Technology of Advanced Materials 20(1): 876-901.

Lee, J-H. \& Kim, Y-J. 2014. Hydroxyapatite nano fibers 
fabricated through electrospinning and sol-gel process. Ceramics International 40(2): 3361-3369.

Lee, L.M. \& Ahmad, A.M. 2013. Interfacial reaction of Sn$\mathrm{Ag}-\mathrm{Cu}$ lead-free solder alloy on $\mathrm{Cu}$ : A review. Advances in Materials Science and Engineering 2013: Article ID. 123697.

Li, H., An, R., Wang, C. \& Jiang, Z. 2015. In situ quantitative study of microstructural evolution at the interface of $\mathrm{Sn} 3.0 \mathrm{Ag} 0.5 \mathrm{Cu} / \mathrm{Cu}$ solder joint during solid state aging. Journal of Alloys and Compounds 634: 94-98.

Liu, J., Zhao, H., Li, Z., Song, X., Zhao, Y., Niu, H., Tian, H., Dong, H. \& Feng, J. 2018. Microstructure evolution, grain morphology variation and mechanical property change of $\mathrm{Cu}-\mathrm{Sn}$ intermetallic joints subjected to high-temperature aging. Materials Characterization 135(November): 238-244.

Mo, L., Wu, F. \& Liu, C. 2015. Growth kinetics of IMCs in Cu$\mathrm{Sn}$ intermetallic joints during isothermal soldering process. Proceedings - Electronic Components and Technology Conference. pp. 1854-1858.

Rabiatul Adawiyah, M.A. \& Saliza Azlina, O. 2018. Comparative study on the isothermal aging of bare $\mathrm{Cu}$ and ENImAg surface finish for Sn-Ag-Cu solder joints. Journal of Alloys and Compounds 740: 958-966.

Satyanarayan \& Prabhu, K.N. 2013. Spreading behavior and evolution of IMCs during reactive wetting of sac solders on smooth and rough copper substrates. Journal of Electronic Materials 42(8): 2696-2707.

Tang, Y., Luo, S.M., Li, Z.H., Hou, C.J. \& Li, G.Y. 2018. Morphological evolution and growth kinetics of interfacial $\mathrm{Cu} 6 \mathrm{Sn} 5$ and $\mathrm{Cu} 3 \mathrm{Sn}$ layers in low-Ag Sn-0.3 Ag- $0.7 \mathrm{Cu}-$ $\mathrm{XMn} / \mathrm{Cu}$ solder joints during isothermal ageing. Journal of Electronic Materials 47(10): 5913-5929.

Wang, C., Li, M., Chiu, C. \& Chang, T. 2018. Kinetic study of solid-state interfacial reactions of p-type $(\mathrm{Bi}, \mathrm{Sb}) 2 \mathrm{Te} 3$ thermoelectric materials with $\mathrm{Sn}$ and $\mathrm{Sn}-\mathrm{Ag}-\mathrm{Cu}$ solders. Journal of Alloys and Compounds 767: 1133-1140.

Wang, Y., Wang, G., Song, K. \& Zhang, K. 2017. Effect of $\mathrm{Ni}$ addition on the wettability and microstructure of Sn2.5Ag0.7Cu0.1RE solder alloy. Materials \& Design 119: 219-224.

Wu, Y., Jennifer, A.S., Cyrus, P., Ann Foster, L., Marshall, J.L., Jacobs, E.G. \& Pinizzotto, R.F. 1993. The formation and growth of intermetallics in composite solder. Journal of Electronic Materials 22(7): 769-777.

Xiao, H., Li, X.Y., Zhu, Y.X., Yang, J.L., Chen, J. \& Guo, F.
2013. Intermetallic growth study on $\mathrm{SnAgCu} / \mathrm{Cu}$ solder joint interface during thermal aging. Journal of Materials Science: Materials in Electronics 24(7): 2527-2536.

Yang, M., Ko, Y-H., Bang, J., Kim, T-S., Lee, C-W. \& Li, M. 2017. Effects of Ag addition on solid-state interfacial reactions between $\mathrm{Sn}-\mathrm{Ag}-\mathrm{Cu}$ solder and $\mathrm{Cu}$ substrate. Materials Characterization 124: 250-259.

Yu, D.Q., Wu, C.M.L., Law, C.M.T., Wang, L. \& Lai, J.K.L. 2005. Intermetallic compounds growth between $\mathrm{Sn}-3.5 \mathrm{Ag}$ lead-free solder and $\mathrm{Cu}$ substrate by dipping method. Journal of Alloys and Compounds 392(1-2): 192-199.

Zhu, Z., Ma, H., Shang, S., Ma, H., Wang, Y. \& Li, X. 2019. Effect of polycrystalline $\mathrm{Cu}$ microstructures on IMC growth behavior at $\mathrm{Sn} / \mathrm{Cu}$ soldering interface. Journal of Materials Science: Materials in Electronics 30(17): 15964-15971.

Rabiah Al Adawiyah Ab Rahim, Azman Jalar*, Atiqah Mohd Afdzaluddin \& Kim Siow Shyong

Institute of Microengineering and Nanoelectronics (IMEN) Universiti Kebangsaan Malaysia

43600 UKM Bangi, Selangor Darul Ehsan Malaysia

Muhammad Nubli Zulkifli

Universiti Kuala Lumpur (UniKL)

British Malaysia Institute (BMI)

Electrical Engineering Section

Jalan Sungai Pusu

53100 Gombak, Selangor Darul Ehsan

Malaysia

Azman Jalar*

Department of Applied Physics

Faculty of Science \& Technology

Universiti Kebangsaan Malaysia

43600 UKM Bangi, Selangor Darul Ehsan

Malaysia

*Corresponding author; email: azmn@ukm.edu.my

Received: 13 August 2020

Accepted: 27 August 2020 